\title{
Experience as a catalyst of export destinations: The ambidextrous connection between international experience and past entrepreneurial experience
}

\author{
Esteban Lafuente \\ Department of Management, Universitat Politècnica de Catalunya (Barcelona Tech) \\ EPSEB, Av. Gregorio Marañón, 44-50, 08028 Barcelona, Spain \\ E-mail: esteban.lafuente@upc.edu \\ Yancy Vaillant \\ Department of Strategy, Entrepreneurship \& Innovation. Toulouse Business School (TBS) \\ 1 Place Alphonse Jourdain, 31068 TOULOUSE Cedex 7, France \\ E-mail: y.vaillant@tbs-education.org \\ Marco Alvarado \\ Universidad Latinoamericana de Ciencia y Tecnología, Costa Rica \\ E-mail:malvaradom@ulacit.ac.cr \\ Ronald Mora-Esquivel \\ Business School, Costa Rica Institute of Technology (ITCR) \\ Business School, 15th Street, 14th Avenue, Cartago, Costa Rica \\ E-mail: rmora@itcr.ac.cr \\ Ferran Vendrell-Herrero \\ Birmingham Business School, University of Birmingham \\ Edgbaston, B15 2TT, Birmingham, UK \\ E-mail: f.vendrell-herrero@bham.ac.uk
}

Working paper version: December 2020

\section{PLEASE CITE AS:}

Lafuente, E., Vaillant, Y., Alvarado, M., Mora-Esquivel, R., Vendrell-Herrero, F. (2021). Experience as a catalyst of export destinations: The ambidextrous connection between international experience and past entrepreneurial experience. International Business Review, 30 (1), 101765. 


\title{
Experience as a catalyst of export destinations: The ambidextrous connection between international experience and past entrepreneurial experience
}

\begin{abstract}
This paper examines how different forms of accumulated exploitable knowledge-i.e., export experience with the current firm and past entrepreneurial experience-stimulate export destinations, defined as the number of foreign markets where businesses sell their products/services. The proposed hypotheses are tested on a unique sample of Costa Rican entrepreneurial businesses for 2017. Results from the sequential deductive triangulation analysis (QUAN $\rightarrow$ qual) reveal that the ambidextrous connection between export experience with the current firm and past entrepreneurial experience is an essential prerequisite for explaining export destination figures. Also, the positive effect of export experience with the current business on export destinations is more prevalent among firms created by serial entrepreneurs. These findings corroborate our argument line on the importance of generative-based learning processes. Furthermore, the results of the qualitative analysis suggest that task-specific international experience and experience gained through past business venturing are relevant micro-foundations of international business expansion in the context of the export destinations of entrepreneurial firms.
\end{abstract}

Keywords: Entrepreneurship, serial entrepreneurs, entrepreneurial experience, generative learning process, internationalization, export destinations.

JEL codes: L26, M13, M2

\section{Introduction}

In this paper, we investigate how different types of experiential knowledge impact export destinations, in terms of the number of international markets targeted by the business. Specifically, the study seeks to identify weather explicit internationally exploitable knowledge, that we link to the international market experience with the current business, and exploratory enabling knowledge resulting from the generative experiential learning from past entrepreneurial activity, interact to stimulate export destinations among entrepreneurial ventures.

The study of business internationalization has developed into a field of research of its own, where researchers have for many years now been expanding the boundaries of knowledge in areas such as international marketing strategy (Li, Liu, \& Bustinza, 2018; Theodosiou \& Leonidou, 2003), foreign entry mode (Laufs \& Schwens, 2014), international knowledge transfers (Ahammad, Tarba, Liu, \& Glaister, 2016), foreign consumer attributes and behaviors (Vendrell-Herrero, Gomes, Collinson, Parry, \& Bustinza, 2018), international entrepreneurship (Jones, Coviello, \& Tang, 2011; Knight \& Cavusgil, 2004) as well as international business model innovation and adaptations (Cao, Navare, \& Jin, 2018; Liu, 2020), among many others.

As a result of the evolutionary path of the business internationalization stream, a growing body of research suggests that the ability of organizations to internationalize heavily depends on their diverse stock of knowledge (see, e.g., Love, Roper, \& Zhou, 2016; Schmidt \& Sofka, 2009). Underlying this 
literature is the presumption that knowledge accumulation processes within the firm contribute to overcome the difficulties of internationalization (Fletcher \& Harris, 2012; Westhead, Wright, \& Ucbasaran, 2001). In the specific context of this study, does this imply that explicit internationally exploitable knowledge generated within the current business is the primary conduit that allows entrepreneurs to tackle the challenges of the internationalization process? Furthermore, does congenital knowledge- that we link to the generative-based learning resulting from past entrepreneurial experience-equip entrepreneurs with multifunctional abilities and skills that, in tandem with their exploitative knowledge, contribute to enhance the business' international performance, in terms of export destinations?

Experience is important for entrepreneurs as it contributes to their learning capacity and capabilities to navigate their ventures through complex and challenging settings, such as foreign markets. Capabilities, built on the foundations of an entrepreneur's experiential learning, are consciously developed and deployed to enable firm-level outcomes (Zollo \& Winter, 2002). Whereas a lack of international markets knowledge is often cited by firms as one of the main barriers to export performance (Love et al., 2016; Roper \& Love, 2002), an entrepreneur's accumulated experiential learning enhances their firms' internationally exploitable capabilities in geographically, institutionally and culturally distinct markets (Barkema \& Vermeulen, 1998; Yeoh, 2004).

But not all experiential learning is equal. An entrepreneur's cumulated international market experience with the current business leads to learning benefits that are context-specific (Baron \& Ensley, 2006), which are further exploitable through continued international market activity. On the other hand, past entrepreneurial experience, as that gained by serial entrepreneurs who successively create different business ventures (MacMillan, 1986), is generative-based learning (Cope, 2005). Such experiential learning facilitates the exploratory capabilities of entrepreneurs by helping them carryover and adapt their cumulated knowledge to different contexts so as to better confront unfamiliar situations (Vaillant \& Lafuente, 2019b). Therefore, an entrepreneur's internationally exploitable knowledge coming from export market experience may be supplemented by the exploratory generative knowledge from past entrepreneurial experience to generate ambidextrous capabilities that can contribute to even greater numbers of export market destinations.

To address the proposed research questions empirically and reach our objective, we conduct a mixed method study that follows a sequential triangulation approach (QUAN $\rightarrow$ qual) using a unique primary dataset of Costa Rican novice and serial entrepreneurs for 2017 (Creswell \& Clark, 2017; Stephan, Patterson, Kelly, \& Mair, 2016). By employing a sequential triangulation approach, this study adopts a microfundational approach that seeks to more accurately contrast a series of three theoretically-based hypotheses connecting different forms of the entrepreneurs' experiential knowledge (i.e., international market operations with their current ventures as well as past entrepreneurial activity) to business-level outcomes (export destinations). This way, notwithstanding studies specifically addressing international entrepreneurship (Rialp, Rialp, \& Knight, 2005), our 
research follows the tradition of recent work emphasizing the individual as a basic building block of firm internationalization (Gavetti, 2012). This microfoundational approach to international business research proposes to explain the origins of the macro as the result of the individual-level concept (Barney \& Felin, 2013; Liu, 2020; Liu \& Huang, 2018). The adoption of a microfoundation lens helps to understand the links that an individual-level characteristic such as experiential entrepreneurial learning can have on the business-level processes, routines and international trajectories of their ventures (Felin et al., 2012).

Costa Rica is an attractive setting for this study due to its international business profile (Alonso \& Leiva, 2019; Alvarado, Lafuente, \& Mora-Esquivel, 2019; Lafuente, Vaillant, \& Leiva, 2018). Despite having a relatively small domestic market, Costa Rica’s industry has been able to prosper, often in high value-added industries and functions within global value chains. The country's economic performance and competitiveness is atop of the Latin American region, together with Chile (OECD, 2016). Cost Rica's manufacturers are driven to export in order to expand their markets and reach the scale often required for competitive production. This has meant that exports account for $32.80 \%$ of the country's GDP in 2016; as compared to the average of 27.90\% for OECD member countries (OECD, 2016; World Economic Forum, 2016). Costa Rica’s economic strategy has promoted the diversification of productive activities, which in turn has increased the relevance of manufacturing sectors (manufacturing exports grew from 29.80\% of total exports in 1980 to $57 \%$ in 2015), high-tech electronic products and, more recently, manufacturing goods linked to the medical industry (medical devices and instruments) (Monge-González et al., 2017; OECD, 2017). Additionally, the greater involvement of Costa Rican businesses in global value chains has led to the rise of exports of business services, in particular, knowledge-based informatics and information services (Lafuente, et al., 2018).

Prior work suggests that entrepreneurs and their SMEs operating in emerging markets are increasingly active internationally (Lafuente, Stoian, \& Rialp, 2015; Li et al., 2018; Martins, GomézAraujo, \& Vaillant, 2015; Miocevic \& Crnjak-Karanovic, 2011; Vendrell-Herrero, Gomes, Mellahi, \& Child, 2017). However, most of the literature on Latin American markets focuses on the international behavior of large firms (e.g., Aulakh, Kotabe, \& Teenge, 2000; Martincus \& Carballo, 2008). International business scholars highlight the internationalization of small firms from emerging economies as a fruitful research avenue (Aguilera, Ciravegna, Cuervo-Cazurra, \& Gonzalez-Perez, 2017; Peiris, Akoorie, \& Sinha, 2012; Vendrell-Herrero et al., 2017). In this sense, the proposed analysis contributes to the literature by identifying how current export experience and past entrepreneurial experience influence export destinations in SMEs. Also, by exploring from a qualitative perspective how specific export market experience interacts with the generative-based experiential learning processes of serial entrepreneurs, our analysis contributes to unveil various underlying micro-foundational mechanisms fueling superior levels of export destinations. 
The results of the proposed sequential triangulation model indicate that the number of export market destinations of firms is favored by the ambidextrous nature of the cumulated experiential learning of their entrepreneurs.

\section{Background theory and hypotheses development}

\subsection{Microfoundations lens}

Microfoundations has attracted significant research interest over a wide swath of areas in the last decade (Felin, Foss, \& Ployhart, 2015; Liu \& Huang, 2018). The microfoundations approach is not a theory but a way of thinking about macro outcomes. It seeks to find explanations for organizational outcomes, such as international market performance and competitive advantage by examining lower level phenomena like the origin and development of managerial and organizational capabilities (Felin et al., 2012; Liu \& Huang, 2018). The adoption of a microfoundation lens can be organized into three overarching categories: (1) individuals, (2) processes and routines and (3) structure and design, where each category has an interactive relationship with other components of the organization (Felin et al., 2012). As such, the characteristics of the individual entrepreneurs, such as cumulated experiential learning, are likely to influence the export trajectories of the organizations they pilot.

Dynamic capabilities (Teece, 2007) is an important area for application of the microfoundations approach. As experience has been conceptualized as a microfoundation of knowledge (Liu \& Almor, 2016), it is suggested that entrepreneurial learning opportunities can play an important role in a firm's ability to identify opportunities in the environment (Volberda, Foss, \& Lyles, 2010). Salvato and Rerup (2011) explore the relationship between routines and capabilities in the development of dynamic capabilities where routines are defined as complex and analytic processes that extensively rely on existing knowledge, linear execution, and repetition (Eisenhardt \& Martin, 2000). Capabilities, built on the foundations of an entrepreneur's experiential learning, are consciously developed and deployed to enable firm-level outcomes (Liu, 2020; Zollo \& Winter, 2002). This research therefore adopts the microfoundation approach to build a greater understanding of the development of export diversity, a firm-level outcome, as a result of the cumulated experiential learning of its entrepreneur.

\subsection{International market experience driving internationally exploitable knowledge}

From a macroeconomic perspective, export destinations, that is, the number of foreign markets where local businesses sell their goods and services is attractive for the local economy. This is because the number of export destinations evidences a diversified trade market, increases the potential sources of external knowledge absorption, and limits the exposure and dependence on any one single foreign market. From a micro perspective, recent studies suggest that successful internationalization is favored by the capacity of the business to export to a wide array of destinations (Bastos et al., 2018; Boehe \& Jiménez, 2018; Brambilla, Lederman, \& Porto, 2012). However, the complexity of international market expansion becomes even more intricate when an entrepreneur's venture is simultaneously 
active in many different international markets (Lafuente, Vaillant, \& Moreno, 2018). Exporting to different destinations therefore becomes a high-skilled knowledge-intensive task even when the nature of the goods or services that are traded abroad are relatively low-skill (Brambilla et al., 2012).

Many authors emphasize from a process perspective to internationalization the essential experiential aspects of learning for export market performance (Casillas, Barbero, \& Sapienza, 2015; Johanson \& Vahlne, 1977; Love et al., 2016). As such, these authors suggest that experiential learning relative to export activities arises as a "consequence of operating in an international context" (Love et al., 2016, p. 807) and such knowledge is difficult to acquire in any alternative manner. Therefore, experience is considered essential for increased export destinations (Vaillant et al., 2006).

An entrepreneur's cumulated international market experience with the current business leads to learning benefits that are further exploitable only through additional international market expansion (Martins, Goméz-Araujo, \& Vaillant, 2014). Many empirical studies on export performance have mistakenly used business age as a proxy for experience (e.g. D’Angelo, Majocchi, Zucchella, \& Buck, 2013; Majocchi, Bacchiocchi, \& Mayrhofer, 2005). Love et al. (2016) demonstrated while business age may be an (indirect) indicator of experience, it does not significantly explain export performance. Rather than business age, the number of years that a firm has been active in international marketsi.e., export experience - is found to be a more accurate indicator of internationalization capabilities and explain future international performance (Ganotakis \& Love, 2012).

A lack of knowledge about international markets is often cited by firms as one of the main barriers to export performance (Love et al, 2016; Roper \& Love, 2002). Internationalization is in itself a process of knowledge and learning accumulation that takes place within the firm (Barkema \& Vermeulen, 1998; Li, Liu, \& Bustinza, 2018; Yeoh, 2004). The entrepreneurs' exposure to international markets enhances their firms' internationally exploitable knowledge that can serve their venture in geographically, institutionally and culturally distinct markets. Thus, experience in terms of time that an entrepreneur's venture has been active within international markets is an experiential learning leading to internationally exploitable knowledge that stimulates export market expansion and diversity. From these arguments, the following hypothesis emerges:

H1: Accumulated export experience with the current business positively impacts the number of export market destinations targeted by the business.

\subsection{Past entrepreneurial experience driving exploratory generative knowledge}

The premise that a firm's current international market experience is the only indicator of knowledge acquisition adequate for export performance does not encompass well the generative learning benefits of past entrepreneurial experience gained by serial entrepreneurs. Empirically, the generative-based learning resulting from the entrepreneurial experience of serial entrepreneurs has been found to influence expectations and strengthen the perception of preparedness of serial entrepreneurs (Headd, 2003; Simmons, Carr, Hsu, \& Shu, 2016) leading to superior performance in 
terms of employment (Van Praag \& Cramer, 2001), economic value (Parker, 2013) innovativeness (Ucbasaran et al., 2010; Vaillant \& Lafuente, 2019a) and international market propensity (Lafuente et al., 2018; Vaillant \& Lafuente, 2019b). Baron and Ensley (2006) found that as opposed to inexperienced entrepreneurs, serial entrepreneurs are better able to detect meaningful patterns. Therefore, because of this generative-based knowledge, serial entrepreneurs are able to identify not only more opportunities (Ucbasaran et al., 2009), but also better opportunities (Lafuente et al., 2018). Even when a serial entrepreneur has no prior international market experience, the generative-based learning process and resulting acquired knowledge makes serial entrepreneurs able to understand and deal with export market challenges.

Because of the compounded entrepreneurial complexity of simultaneous activity in many different international markets, exporting to multiple destinations becomes a high-skilled knowledgeintensive task even when the nature of the goods or services that are traded abroad are relatively lowskill (Brambilla et al., 2012; Vaillant, Lafuente, \& Bayon, 2019). Novice entrepreneurs may find it too difficult to simultaneously operate in geographically, institutionally and culturally distinct markets, and may be tempted to adopt a more concentrated international stance where their ventures limit their international activities to one single foreign market (Love, Roper, \& Zhou, 2016). Entrepreneurs with past business experience on the other hand, because they have gained the benefits of the generative experiential learning from their past ventures, may be in a better position to surpass these complexities so as to better explore and optimize a diversity of international market opportunities.

In this line, Lafuente, Vaillant, Vendrell-Herrero, and Gomes (2018) and Vaillant and Lafuente (2019) have linked the past business experience of serial entrepreneurs to the international activity levels of their subsequent businesses. Serial entrepreneurs were found to benefit from the generative nature of experiential entrepreneurial learning that makes them better comprehend and manage future challenges, which they can do across a broader range of new situations (Cope, 2005; Huber, 1991; Keith, Unger, Rauch, \& Frese, 2016; Toft-Kehler, Wennberg, \& Kim, 2014). This congenital knowledge that the serial entrepreneur brings to their subsequent ventures is coupled with vicarious knowledge and the greater ease of searched knowledge due to the generative-base process coming from prior experiential entrepreneurial learning (Huber, 1991).

The knowledge and skills required to successfully confront the complexities of exporting to multiple market destinations has a predominantly experiential nature (Yeoh, 2004). Entrepreneurs who are better able to recognize and explore various simultaneous international opportunities are able to do so because they possess relevant generative-based experiential knowledge that help them accomplish such tasks, irrespective of the nature of their past entrepreneurial experience. These arguments and evidence lead to hypothesize that:

H2: Entrepreneurs' serial experience positively impacts the number of export market destinations targeted by the business. 


\subsection{Ambidextrous experiential-based knowledge}

International market experience is likely to lead to a task and firm-specific knowledge where the learning benefits involved contribute mainly to capabilities exploitable in replicable international contexts. But, an entrepreneur's internationally exploitable knowledge coming from export market experience may be supplemented by the exploratory generative knowledge from past entrepreneurial experience to generate ambidextrous capabilities that can contribute to export to an even greater number of market destinations.

Entrepreneurs with international experience are likely to have accumulated knowledge about customers and suppliers, networks of contacts as well as market specific information (Sarasvathy et al., 2013; Ucbasaran et al., 2006). This type of market specific cognition has been described as contextual experience (Rosa, 1998; Wright et al., 1997) as well as technology or task experience (Westhead et al., 1999). This type of experiential learning leads to knowledge exploitable only within similar contexts.

It has been argued that international market experience creates knowledge that provides individuals with specific information and learning, including tacit knowledge and information particular to the international market where the entrepreneur's venture operates (Love et al., 2016). The usefulness of such knowledge may be limited in other more diverse export markets that do not share many of the commercial, institutional and cultural characteristics of the international destinations that the firm currently supplies.

From an export destinations standpoint, entrepreneurs that have learnt from their venture's international experience would tend to enter relatively 'easy' markets first, where they can better exploit their cumulated international market experience. As they gather further exploitable experiential international knowledge, they can progressively enter more distant/different markets without being overly exposed to the liability of foreignness that a firm without such experience would likely face (Love et al., 2016). The firm's gradual international market expansion would allow entrepreneurs with international experience to best exploit the gained knowledge by remaining within the progressively expanding boundaries of what is contextually familiar. In unfamiliar international contexts, previous experience is likely to have less exploitable value leading to a declining experiential learning benefit.

But if such entrepreneurs with cumulated exploitable knowledge gained through international market experience would happen to also have developed the exploratory capabilities coming from the generative learning process of past entrepreneurial experience, their firms' potential export market destinations would be much less constrained (Rialp et al., 2005). Therefore, it is likely that the exploitative nature of accumulated export experience would benefit from the exploratory stimulus of generative-based experiential learning to provoke greater international market diversification, in terms of the number of foreign market destinations targeted by the firm. International market experience with their current business will give entrepreneurs experiential knowledge of a specific export setting, and they may also benefit from some vicarious knowledge. But, with the added generative-based 
agility that helps entrepreneurs better confront unknown situations and context, the exploitation of export market experience will more adequately prepare them to explore more diverse foreign market expansion. The generative-based knowledge of serial entrepreneurs is conducive to such international behavior, which if it coincides with exploitative benefits of export experience, is likely to lead to an international ambidextrous cognition on the part of the entrepreneur that favors export performance in terms of export market destinations.

To sum up, it has been argued that experience stimulates the microfoundations of knowledge (Liu \& Ambor, 2016). To fully realize the ambidextrous potential of combined international market experience and past entrepreneurial experience such contrasted types of microfoundations should withstand the potentially resulting competing tensions (Junni et al., 2015). Arguably, contrasted international market experience would sway entrepreneurs to activate strategies within those markets that have proven themselves more receptive to the business' offer. This would create a tension that may constrain the joint exploitation of the two types of microfoundations (see, e.g., Junni et al., 2015; Love et al., 2016). On contrary when tensions are surmounted, the ambidextrous process connecting international market experience and past entrepreneurial experience would lead to a broader, complementary stock of knowledge that would likely open the door for the full realization of new strategies, including the exploration of new foreign destinations (Huber, 1991; Keith, et al., 2016; Toft-Kehler et al., 2014).

A serial entrepreneur with export experience within her/his current venture will benefit from both international experiential knowledge and the generative congenital knowledge resulting from past entrepreneurial experience, such that the entrepreneur may not only be better able to explore and diversify internationally, but also better able to exploit the opportunities within each individual export market. These arguments and evidence lead to hypothesize that:

H3: The positive impact of accumulated export experience over export market destinations will be greater in the case of serial entrepreneurs.

\section{Data and method}

\subsection{Data and variable definition}

The data used to test the proposed hypotheses comes from a unique dataset of Costa Rican business owners-managers for the year 2017. As part of a research project, the questionnaire employed in this work was designed specifically for the purposes of this study by a research team at the Costa Rica Institute of Technology (ITCR).

Entrepreneurs are the potential respondents, and they were approached face-to-face with a request to participate in the study. Participants received confirmation of confidentiality and the research team leading the investigation offered feedback on the survey results to the participating businesses in order to encourage entrepreneurs to answer. Data collection was achieved through self-administrated, structured interviews, where the entrepreneur or the manager was asked to answer essentially closed 
questions. The surveying was carried-out by a team from the Costa Rica Institute of Technology (ITCR). It should be kept in mind that, following the standards recommended in the literature (Colton \& Covert, 2007) the questionnaire was subject to a pre-test, which involved the evaluation of the instrument by two academics and one manager with more than ten years of market experience, in order to correct potentially ambiguous or confusing questions.

The information was collected between June and August 2017. In a first stage, a total number of 530 owners of Costa Rican SMEs operating in different industries (i.e., manufacturing, trade, consumer services, and business service sectors) were invited to participate in the study. Given our interest in evaluating the role played on export performance of both past entrepreneurial experience and export market experience in the current business, we decided to focus on those entrepreneurial businesses operating in manufacturing, retail, and business service sectors. Also, 15 cases with incomplete data were dropped from the sample. Therefore, the final sample comprises information for 82 valid questionnaires, which represents an effective response rate of $15.47 \%$.

Looking at the profile of the sampled firms, note that $82.93 \%$ of SMEs are micro-businesses with up to ten employees, while $17.07 \%$ of SMEs have more than 10 employees. Also, 53.66\% of the surveyed firms are located in the capital region (San Jose). Finally, 11 businesses operate in manufacturing sectors (13.41\%), retail and consumer services (34 firms) represent $41.46 \%$ of the sample, while 37 businesses operate in knowledge-intensive business-service sectors (45.12\%).

\subsection{Variable definition}

Dependent variables. The dependent variable used in this study to analyze the international performance of the sampled businesses is export destinations. This variable is calculated as the total number of foreign markets where the business sells its products/services. Prior work has considered this variable a proxy of internationalization expansion and success (Alvarado et al., 2019; Bastos et al., 2018; Brambilla et al., 2012).

At this point, two important considerations are in order. First, we decided not to use export intensity as a dependent variable. Respondents were asked to indicate their businesses' export intensity on a quartile-based scale. However, most of the sampled businesses report an export intensity level that falls in the $1 \%-25 \%$ interval (83.33\%), while the remaining $16.67 \%$ of business export between $25 \%$ and $50 \%$ of their products/services. This descriptive result is consistent with other similar studies conducted in developed (Eaton, Kortum, \& Kramarz, 2004) and developing economies (Brambilla et al., 2012; Martins et al., 2015; Vaillant et al., 2019). Given the distribution of this ordinal variable, an ordered probit model regressing export intensity against past entrepreneurial experience would produce inconsistent results closer to a probit model in which the perfect collinearity between export market experience and the dependent variable would contaminate the analysis and the conclusions that can be drawn from it. We ran a robustness check in order to verify this intuition. This complementary analysis employs probit and ordered probit models to study the influence of past entrepreneurial 
experience (and the set of independent variables described above) on export propensity and intensity, respectively. The findings presented in Table A1 of the Appendix corroborate our arguments. Results indicate that both the probit and ordered probit models produce a similar result for the coefficient linked to past entrepreneurial experience. Also, in the ordered probit model all independent variables turn not significant for the export intensity category including firms that export between $26 \%$ and $50 \%$, a result that may originate from the highly skewed distribution of export intensity.

Second, unfortunately, entrepreneurs of exporting businesses did not provide detailed data on the exact foreign markets where they sell their products/services. We are aware that the partial availability of information on export destinations somewhat limits our analysis; however, and similar to prior work (e.g., Alvarado et al., 2019; Eaton et al., 2004; Love et al., 2016; Manova \& Zhang, 2012), we are confident that the proposed analysis based on the number of export markets can offer important nuances of the relevance of the interplay between export market experience and past entrepreneurial experience for export destinations.

The descriptive statistics presented in Table 1 indicate that $21.95 \%$ of businesses export. A further scrutiny of the data reveals that export destinations among the sampled businesses is highly right-skewed: $9.76 \%$ of businesses export to one country (44.44\% of exporters), $4.88 \%$ of businesses export to two foreign market destinations (22.22\% of exporters), $3.66 \%$ of businesses operate in three foreign markets (16.67\% of exporters), while the remaining 3.66\% of firms export to more than three international destinations.

----- Insert Table 1 about here -----

Export experience with the current business. We employ a censored variable to operationalize international market experience. In this sense, for businesses involved in international activities, export experience is defined as the number of years of export experience of the current business. This variable takes the value of zero for non-exporting businesses. Average export experience is 2.68 years among the sampled businesses (Table 1), and for the group of exporting businesses the average export experience is 12.22 years (range: 1-27 years).

Past entrepreneurial experience. The prior entrepreneurial experience represents a key source of generative-based experiential knowledge (Vaillant \& Lafuente, 2019b). Serial entrepreneurs are expected to raise the export destinations of their subsequent business ventures. Respondents reported whether they have owned a business in the past (yes $=1$, no $=0$ ). As we indicated above, the generative learning process of entrepreneurial experience is not task specific but rather contributes to improve the outcomes and effectiveness of serial entrepreneurs across a broader range of organizational domains. Therefore, the export activity of the current business is the result of a decision-making process in which cognitive schemas and accumulated generative-based knowledge resulting from past entrepreneurial experience play a key role. By definition, novice entrepreneurs 
have no entrepreneurial experience. Descriptive statistics in Table 1 show that $18.29 \%$ of the sampled entrepreneurs have created at least one business in the past. Also, figures in Table 2 highlight the greater international activity of serial entrepreneurs: $26.67 \%$ of exporters are businesses created by serial entrepreneurs (export destinations: 3.75 countries), while the rate of exporters among novice entrepreneurs without past entrepreneurial experience is 20.90\% (export destinations: 1.86 countries).

----- Insert Table 2 about here -----

Control variables. We control for gender, entrepreneur's age, management studies, labor market experience, business size, business age, use of new technologies, industry and location in the different model specifications. The gender variable takes the value of one for male entrepreneurs (zero for female entrepreneurs), whereas age is expressed in years. We use a dummy variable (yes $=1, \mathrm{no}=0$ ) to identify entrepreneurs with management studies. Labor experience is measured as the total number of market experience of the sampled entrepreneurs. These variables have been used in prior studies on entrepreneurship and on internationalization (see, e.g., Alvarado et al., 2019; Boehe \& Jiménez, 2018; Brambilla et al., 2012; Lafuente et al., 2015; Vaillant \& Lafuente, 2019b).

Concerning the business-related control variables, size is measured via a dummy variable that captures if the business has less than 10 employees (yes $=1$, no $=0$ ), while business age is expressed in years since the current business started its operations. These two variables measure the vulnerability of the firm to market conditions due to liabilities of smallness and newness (Das, Roberts, \& Tybout, 2017; Love et al., 2016; Ucbasaran, Shepherd, Lockett, \& Lyon, 2013). Entrepreneurs were asked to provide information about the use of new technologies in their businesses. Following Raschke (2010), the adoption of new technologies (developed and available in the marketplace within the last 2 years) in production processes is captured by a dummy variable taking the value of one for entrepreneurs who state that such technologies are used in their business. Respondents also indicated the business' primary activity with regard to the following categories: manufacturing, trade and retail, as well as knowledge-intensive business-service sectors. Based on these data, a set of industry dummy variables were created. Regarding geographic location, we use a dummy variable (yes $=1$, no $=0$ ) to identify businesses headquartered in the capital region (San José). Finally, the variables entrepreneur's age, export experience, labor experience, business size and business age were logged to reduce skewness.

\subsection{Method}

Although the proposed hypotheses are testable through common quantitative techniques we resort to methodological triangulation methods (Greene, Caracelli, \& Graham, 1989). More concretely, we employ sequential methodological triangulation (QUAN $\rightarrow$ qual) (Morse, 1991; Morse \& Niehaus, 2009; Stephan et al., 2016; Teddlie \&Tashakkori, 2009) to ensure a more comprehensive analysis of the main nuances of export market destinations in entrepreneurial businesses created by serial 
entrepreneurs having more, or less, experience in international markets. The deductive methodological triangulation "is the use of at least two methods, usually quantitative and qualitative to address the same research problem” (Morse \& Niehaus, 2009, p. 120). The main advantage of the sequential triangulation approach is to raise accuracy of information and to generate a more holistic picture of the phenomenon analyzed (Bryman \& Bell, 2015).

In the first stage of the sequential methodological triangulation we examine the impact on export destinations of past entrepreneurial experience and export experience with the current business. Here, the dependent variable is the count integer of the total number of export market destinations in 2017 (Table 1). Therefore, a negative binomial regression is the econometric technique chosen to evaluate export destinations as a function of the independent variables related to past entrepreneurial experience, export experience and the control variables. This approach is the most appropriate when the dependent variable is a count number exhibiting a highly skewed distribution (Greene, 2003; 2008). In this case, the full model to be estimated has the following form:

Export

$$
\begin{aligned}
\text { destinations }_{i} & =\beta_{0}+\beta_{1} \text { Export experience }_{i}+\beta_{2} \text { Past entrepreneurial experience }_{i} \\
& +\beta_{12} \text { Export experience }_{i} \times \text { Past entrepreneurial experience }_{i} \\
& +\beta_{3} \text { Entrepreneur's controls }_{i}+\beta_{4} \text { Business controls }_{i}+\varepsilon_{i}
\end{aligned}
$$

In equation (1) $\beta_{0}$ is the constant term, $\beta_{j}$ is the vector of coefficients estimated for the $j t h$ independent variable, and $\varepsilon_{i}$ is the disturbance term estimated for each individual in the sample (i).

In terms of the study hypotheses, we expect that $\beta_{1}>0$ and $\beta_{2}>0$ to confirm that among exporters, export experience with the current business (H1) and past entrepreneurial experience (H2) are positively correlated with the business' export destinations, respectively. Similarly, a positive result for the coefficient linked to the interaction term between export experience and past entrepreneurial experience $\left(\beta_{12}>0\right)$ will corroborate that, as compared to novice entrepreneurs, accumulated export experience with the current business will have a greater positive impact over the number of export destinations of serial entrepreneurs (H3).

To complement the variance-based model (equation (1)), the second stage of the sequential deductive triangulation model (Morse, 1991) employs a qualitative analysis in order to better understand if a firm's export destination figures benefit from the ambidextrous interlocking between the past entrepreneurial experience and export market experience of its entrepreneur (Van de Ven, 2007). Because the study's research objective is largely a variance problem statement, the sequential method used is dominated by the quantitative variance model described above, and only supplemented by the complementary analysis of the collected qualitative data. We are not attempting in this study to delve into the much more complex 'how' or 'why' questions, as these fall far beyond the intended 
scope of our set research objective. The use of a sequential complementary qualitative analysis mainly serves to address the 'soft' components that are key to our study, namely experiential learning and cumulated knowledge. Quantitatively, we can capture experience as well and the performance output (export destination figures) that we tie together with the described underlying theoretical foundations. But the concrete experiential learning can only be inferred, as learning is nonquantifiable. We therefore use qualitative data to explain, in more detail, our quantitative results. Contrary to qualitative techniques that serve to combine different methods in order to address research questions requiring holistic analysis, the sequential method used in our study mostly attempts to complement through secondary method the results obtained by the primary research method.

We therefore conducted in-depth structured conversations with entrepreneurs about the main characteristics of their past entrepreneurial experience and the export market experience they have cumulated with their current businesses to see what may have been transposed in the form of firmlevel capabilities that can facilitated export market expansion. This qualitative analysis allows us to detect the analyzed ambidextrous process connecting export experience with the current business and past entrepreneurial experience (input) that may yield to exporting to a greater number of destinations (output). While the information for the quantitative analysis was collected between June and August 2017, the interviews with entrepreneurs were conducted between August and September 2018. The interviews lasted a minimum of 20 minutes.

Following the methodological design of this method (Morse \& Niehaus, 2009), we have contacted four businesses included in the final sample used in the study. The four cases for the qualitative analysis were selected based on their appropriateness for the studied objectives rather than randomness (Greene et al., 1989). Therefore, the studied entrepreneurs were deliberately chosen from a purpose-based premise to highlight the contrast of different potential scenarios of interest for the purposes of our study: serial entrepreneurs with different levels of export market experience with their current business (low and high), and serial entrepreneurs whose firms export to a different number of markets (different export destination level: low and high).

For the face-to-face structured interviews exploratory questions were used. At the beginning of the interview, entrepreneurs were given a brief description of the analyzed organizational framework (Greiner, 1972, Liu, 2020), which focuses on the role of the challenges that businesses face in their internationalization trajectories and on the analyzed sources of experiential knowledge that contribute to alleviate these challenges. The objective of this framework is to assist the interviewed entrepreneurs in organizing their answers. Therefore, by using the organizational development framework the conversations were deliberately guided towards the subjects of the entrepreneurial experience of entrepreneurs and the characteristics of the businesses created in the past by the selected serial entrepreneurs. Prior work supports the suitability of this approach for the analysis of small businesses (Gilbert, McDougall, \& Audretsch, 2006; Liu, 2020). 
Note that two of the interviewed entrepreneurs run firms in business service sectors (i.e., consulting and software development), while the remaining two businesses operate in manufacturing sectors (i.e., manufacturing of material to support marketing campaigns and manufacturing of cosmetic products using natural ingredients).

\section{Results}

This section presents the empirical findings of the study. Results in section 4.1 quantitatively test the proposed hypotheses by using the negative binomial regression models presented in equation (1). Section 4.2 adopts a qualitative approach to analyze how both 'export experience of the current business' and 'past entrepreneurial experience' contribute to export market destinations.

\subsection{Quantitative analysis: Regression results}

This section presents the results of the quantitative analysis. The first model in Table 3 examines the specific influence of export experience with the current business and past entrepreneurial experience on export destinations, while model 2 analyzes the joint impact on export destinations of export experience and past entrepreneurial experience. To evaluate the threat of collinearity, we computed the average inflation factor (VIF) for all independent variables. In all model specifications presented in Table 3, the average VIF values are below the commonly used cut-off threshold of ten. More concretely, the average VIF for the variables included in the first model specification is 1.91 (range $=1.09-5.17$ ), while in the case of the second model the average VIF is 1.94 (range $=1.15-5.38$ ). The results for this diagnostic test do not raise collinearity concerns.

From Table 3, the main results for control variables show that the number export destinations is positively correlated with business size and the attainment of management studies, that is, mediumsized firms and businesses ran by entrepreneurs with management studies export to a greater number of destinations. These results are consistent across model specifications (Table 3).

Concerning the key findings of the study, the results highlight the relevance of identifying the different types of experience that entrepreneurs accumulate in their current business (Love et al., 2016). Instead of market experience (measured via business age), the results indicate that the accumulated experience in international markets is what really increases export market destinations.

----- Insert Table 3 about here -----

The first hypothesis of this study (H1) proposes that accumulated export experience with the current business positively impacts the number of export market destinations targeted by the business. The result in model 1 of Table 3 is in accordance with this hypothesis. From an organizational learning perspective, internationalization can be conceived as a process of knowledge accumulation that occurs within the firm (Barkema \& Vermeulen, 1998; Yeoh, 2004). Our results suggest that the accumulation 
of experience in international markets gives businesses specific knowledge that can be exploited to overcome the difficulties and uncertainties of international business activity (Westhead et al., 2001).

Additionally, the results in model 1 reveal that serial entrepreneurs run businesses that export to a greater number of market destinations than novice entrepreneurs. The findings in model 1 of Table 3 give support to the second hypothesis (H2): businesses created by serial entrepreneurs export to a greater number of market destinations as compared to businesses created by novice entrepreneurs. This result is in line with the argument that, because of their greater generative-based experiential knowledge and skills, serial entrepreneurs are likely better able to explore various international opportunities simultaneously and successfully achieve the tasks associated with these internationalrelated opportunities, irrespective of whether their prior entrepreneurial experience was international in nature (Love et al., 2016; Yeoh, 2004).

Concerning the model estimating the moderating effect of past entrepreneurial experience in the relationship between export experience and export destinations, results in model 2 of Table 3 underline the relevance of past entrepreneurial experience. The findings suggest that the positive effect of export experience with the current business on export destinations is more prevalent among businesses created by serial entrepreneurs.

To aid in the interpretation of the results, we plot the interaction term between the serial entrepreneur dummy and the export experience variable based on estimates from model 2 (equation (1)). The results are presented in Figure 1. In the figure, the vertical axis indicates the predicted values of export destinations (number of foreign markets targeted by businesses), while the horizontal axis indicates the values of export experience. Control variables are set at their sample means.

Figure 1 graphically illustrates that the relationship between export experience and export destinations is positive for both serial and novice entrepreneurs. Although the slope of both estimated effects is positive, the figure shows how the positive relationship between export experience and export destinations is steeper for the group of businesses created by serial entrepreneurs. That is, the effect of export experience is greater among serial entrepreneurs, compared to firms created by novice entrepreneurs. To corroborate this result, we tested if the coefficients linked to serial entrepreneurship and the interaction terms between export experience and the serial entrepreneur dummy have the same significant influence on export destinations. The result of the F-test indicates that these coefficients are significantly different $(\mathrm{F}$-test $=2.98$ and $p$-value $=0.0745$ ). Therefore, we find support for our third hypothesis (H3) that states that that the positive impact of accumulated export experience over export market destinations will be greater in the case of serial entrepreneurs.

\subsection{Qualitative analysis}


This section presents the results of the qualitative analysis. Details on the interviewed entrepreneurs as well as on the main characteristics of their entrepreneurial experience are presented in Tables 4 and 5.

----- Insert Tables 4 and 5 about here -----

From the conversations with the selected entrepreneurs emerged a number of relevant aspects that are worth pointing out. First, from the qualitative comparison of the export experience with the current business and the export destinations of the selected cases, we noted that the export destination figures are greater among those cases reporting more export experience with their current business (Case 2 and Case 4), compared to the two cases with reduced export experience (Case 1and Case 3). This qualitative result is in line with the findings of the quantitative model presented in Table 3 that highlight that, instead of market experience (firm age), experience in international markets is essential for achieve high export destinations figures (Love et al., 2016). Also, the greatest levels of export destinations were found for the entrepreneurs with the greatest past entrepreneurial experience who also reports a high level of export market experience (Case 4). Once more, this qualitative finding is aligned with the results of the regression model that emphasizes that the effect of export market experience on export diversity is greater among serial entrepreneurs (model 2 in Table 3).

Second, regardless the number of businesses created in the past, three out of the four interviewed entrepreneurs expressed similar views that their past entrepreneurial experience was mostly positive (only one entrepreneur manifested a mixed outcome from her past entrepreneurial experience (Case 1)). Although entrepreneurs were asked to assess the outcome of their past entrepreneurial ventures based on different criteria (i.e., sales growth, customer portfolio, and financial performance), we are aware that their valuations have a subjective component. Nevertheless, the reported differences in the valuations made by entrepreneurs tend to suggest that heterogeneous business outcomes are not an impediment to generate and accumulate valuable experiential knowledge that can be used to enhance the internationalization of subsequent ventures created by serial entrepreneurs (Vaillant \& Lafuente, 2019b; Yeoh, 2004).

Third, an important result is the manifest contrast among the interviewed entrepreneurs in what concerns the economic activity of their past businesses and the activity of their current firms. Three out of the four entrepreneurs (Case 1, Case 3 and Case 4) manifested that the economic sector in which their current businesses operate is unrelated to the activity of their previous businesses. Also, they indicated that there is a mostly low-middle connection between the products/services offered by their current businesses and the products/services marketed by past businesses. Because of the highlyspecific nature of his background and of the services he attempts to offer to his customers (software development and IT solutions), only one entrepreneur (Case 2) remarked his deliberate intention to 
operate in the same economic sector. Consequently, the economic activity of his past and current businesses is practically unchanged.

Fourth, entrepreneurs highlighted the relevant role played by talent and the composition of the entrepreneurial team for the internationalization of the studied cases, in terms of export destinations. The four entrepreneurs manifested that they have created their past businesses alone and in partnership, while two entrepreneurs (Case 1 and Case 4) indicated that they have teamed-up with different partners to create their businesses. Furthermore, three of the entrepreneurs (Case 2, Case 3, and Case 4) emphasized that talent is a valuable intangible asset that contributed to reduce the costs of exporting to multiple markets. This is especially evident in the case of the 'Case 4' business that exports to five destinations. The entrepreneur of this business highlighted that differences in the 'ease of doing' internal processes_-including those dealing with internationalization—are evident when comparing the businesses that he created alone viz.-à-viz. those that were created in partnership. More concretely, this entrepreneur manifested that he used to spend a lot of resources (monetary, time, and energy) to engage in international markets, while these efforts were drastically reduced in businesses created in partnership. Effective (more open) communication, and trust in both the partner's capabilities and the quality of their accumulated export experience are invoked as the main factors explaining the relatively superior export procedural efficiency of the business.

Overall the results of the qualitative analysis not only complement the findings of the variancebased model (equation (1)), but also offer valuable insights on the factors facilitating the ambidextrous process analyzed in this study. The qualitative analysis reveals that experience and the composition of entrepreneurial teams are relevant drivers of the ambidextrous experiential-based process. From an organizational perspective, the variability and heterogeneity in the composition of the entrepreneurial teams may constitute a mechanism to increase and diversify the quality of the stock of human capital of entrepreneurial firms (Ucbasaran et al., 2003), which in turn may contribute to enhance the performance of the subsequent ventures created by entrepreneurs.

Additionally, instead of homogeneous experience in terms of the business' economic activity (product/service offering), the findings suggest that heterogeneous task-performance experience and past entrepreneurial experience are relevant micro-foundations of international business in the context of the successful export destinations trajectories of entrepreneurs. In the specific case of this study, export experience helps to create and refine export-related tasks (Love et al., 2016), while the experience gained through the generative learning process of past business venturing opens-up the access to knowledge that equips entrepreneurs with multifunctional capabilities that, in turn, contribute to better-explore and confront uncertain scenarios (Ucbasaran et al., 2009; Lafuente et al., 2018).

\section{Concluding remarks, implications and future research lines}

\subsection{Concluding remarks}


The study presented in this paper looks into whether firms' export market destinations is favored by the ambidextrous nature of the cumulated entrepreneurial experiential learning of their entrepreneurs when international market experience is supplemented by past entrepreneurial experience. As such, the research objective driving our study was to know whether international market experience with the current business and past entrepreneurial experience impacts export market destinations. Specifically, the study sought to identify weather international market experience is important to stimulate export market destinations among entrepreneurial ventures, and if market expansion of these entrepreneurial ventures can potentially be further improved through the exploratory generative experiential knowledge of past entrepreneurial activity.

By employing a sequential triangulation method (QUAN $\rightarrow$ qual) on a unique sample of 82 Costa Rican businesses for 2017, the results of this study provide further evidence that contributes to understand how entrepreneurs capitalize on their experiential-based capabilities. The findings of the quantitative model reveal that both international market experience with the current business and past entrepreneurial experience are important determinants of export destinations. Additionally, it was found that the effect of current export market experience is significantly greater in businesses created by serial entrepreneurs. The analysis of the qualitative data suggests that discrepancies in the effect of export market experience on export destinations may arise from the coupling of heterogeneous knowledge that entrepreneurs accumulate and use in their subsequent businesses to the international market experience of their current businesses. Specifically, the qualitative results suggest that export experience - which creates and refines export-related tasks - and experience gained through the generative learning process of past business venturing — which equips entrepreneurs with distinctive capabilities - are relevant microfoundations of international business in the context of the export trajectory—in our case, export destinations—of entrepreneurial ventures.

\subsection{Academic and managerial implications}

This paper has implications for scholars and practitioners. The implications discussed in this section emerge from the findings of the study, and are strictly connected to our research questions.

From an academic perspective, the results highlight that accumulated experiential-based knowledge is a relevant conduit of increased international market expansion (export destinations). In connection with our first research question ('Does the exploitative knowledge generated within the current business constitute the primary conduit that allows entrepreneurs to tackle the challenges of the internationalization process?'), current export experience contributes to overcome the complexities of international market transactions and expansion (Love et al., 2016), while entrepreneurial experience is followed by a generative learning process that provides cumulative benefits to entrepreneurs that enhances the performance level of their subsequent firms (Simmons et al., 2016; Vaillant \& Lafuente, 2019b). This is an important contribution of this study. While prior research has investigated the effects of serial entrepreneurship on innovation (Ucbasaran et al., 2010), job creation (Van Praag \& 
Cramer, 2001) and economic value (Parker, 2013), this study shows how the exploratory-driven knowledge gained by serial entrepreneurs from their past entrepreneurial experience compliments cumulated export market experience to stimulate greater export market destinations. The ambidextrous combination of internationally exploitable export experience and exploratory generating entrepreneurial experience can lead entrepreneurs to navigate their firms into more daring and diverse international sales destinations.

Prior work emphasizes that exporting decision-making is concerned with the balance between successful exploitation of accumulated experience in current foreign markets and exploratory actions linked to identifying sales opportunities in foreign markets (e.g., Liu \& Almor, 2016). However, and similar to existing research (e.g., Collinson \& Liu, 2019), it was found that the interlocking (or resource relatedness) of different types of accumulated experience is desirable to fully realize the benefits of the export behavior analyzed in this study. This argument contributes to explain the ambidextrous experiential-based process analyzed in this study, which is also connected to our second research question ('Does congenital knowledge equip entrepreneurs with specific abilities and skills that, in tandem with their exploitative knowledge, contribute to enhance the business' international performance, in terms of export destinations?').

For strategy makers, the results of the quantitative analysis, further reinforced by the qualitative data, corroborate that practical experience is an essential prerequisite for learning. Thus, we suggest that entrepreneurs need to turn their attention to the characteristics of the different types of knowledge that they possess when considering the development of international strategies. For example, if export expansion to different market destinations is the desired outcome, the prescription is that novice entrepreneurs should be encouraged to contact experienced entrepreneurs to increase their entrepreneurial and export-related 'know-how'; while serial entrepreneurs with low current export experience should contact support agencies or businesses with export experience in order to create or develop their decisional and operational 'how-know' associated with export market experience.

This implies that export promotion activities should have a more specific and targeted design to successfully promote international expansion. In the specific case of Costa Rica, this aspect is of great relevance for the country's top export promotion agency (Procomer: http://www.procomer.com). This agency supports the exporting activity of local firms by offering specific training and support with country-specific export bureaucracy. These actions may turn sterile if policy makers adopt a generalist approach that does not take into consideration the heterogeneous nature of the different types of experience accumulated by entrepreneurs.

\subsection{Directions for future research}

The results of this study are open to further verification. First, like other studies on export-based internationalization (e.g., Brambilla et al., 2012; Gomes et al., 2018; Lafuente et al., 2015), the data does not permit to verify if differences in export expansion decisions across businesses are conditioned 
by different configurations of accumulated experience. From the results of the qualitative analysis we offer various interpretations of how entrepreneurs combine their different types of accumulated knowledge and experience; however, we do not evaluate how different configurations of accumulated experience (in terms of availability and intensity) condition the choices of new export markets. In this sense, future research should focus on the analysis of the different steps of the export expansion decision-making process.

Second, and in a closely related manner, our data unfortunately does not include a detailed description of the countries where businesses export. However, differences in export expansion decisions across businesses may well be conditioned by the characteristics of the targeted markets. From a strategic management point of view, specifically designed future research on this issue would be valuable. For example, future research on export destinations should include in the analysis the geographic diversity of the foreign markets targeted by firms (Boehe \& Jiménez, 2018; Brambilla et al., 2012).

Finally, the results of this study are based on the analysis of a sample of Costa Rican SMEs. Obviously, we cannot establish that the findings are generalizable to all SMEs. The sampled businesses could have idiosyncratic characteristics that affect their internationalization patterns, in terms of export destinations. Nevertheless, the results presented in this study have a strong conceptual appeal, and are open to future verification. In this sense, future research should further analyze our arguments on the effect of the ambidextrous connection between export experience and past entrepreneurial experience on export performance metrics using data for a wider array of industries operating in different geographic contexts.

Acknowledgements: This research was supported by the Spanish Ministry of Economy, Industry and Competitiveness (Grant No. ECO2017-86305-C4-2-R).

\section{References}

Aguilera, R.V., Ciravegna, L., Cuervo-Cazurra, A., \& Gonzalez-Perez, M.A. (2017). Multilatinas and the internationalization of Latin American firms. Journal of World Business, 52(4), 447-460.

Ahammad, M.F., Tarba, S.Y., Liu, Y., \& Glaister, K.W. (2016). Knowledge transfer and cross-border acquisition performance: The impact of cultural distance and employee retention. International Business Review, 25(1), 66-75.

Alonso, S., \& Leiva, J.C. (2019). Business competitiveness in Costa Rica: a multidimensional approach. TEC Empresarial, 13(3), 28-41.

Alvarado, M., Lafuente, E., \& Mora-Esquivel, R. (2019). Export diversity and the relevance of different forms of market experience. International Journal of Business Environment, 10(3), 209226. 
Aulakh, P.S., Kotabe, M., \& Teegen, H. (2000). Export strategies and performance of firms from emerging economies: evidence from Brazil, Chile, and Mexico. Academy of Management Journal, 43 (3), 342-361.

Barkema, H.G., \& Vermeulen, F. (1998). International expansion through start up or acquisition: A learning perspective. Academy of Management Journal, 41(1), 7-26.

Barney, J. A. Y., \& Felin, T. (2013). What are microfoundations? Academy of Management Perspectives, 27(2), 138-155.

Baron, R. (1998). Cognitive mechanisms in entrepreneurship: why and when entrepreneurs think differently than other people. Journal of Business Venturing, 13, 275-294.

Baron, R., \& Ensley, M. (2006). Opportunity Recognition as the Detection of Meaningful Patterns: Evidence from Comparisons of Novice and Experienced Entrepreneurs. Management Science, 52(9), 1331-1344.

Bastos, P., Silva, J., \& Verhoogen, E. (2018). Export destinations and input prices. American Economic Review, 108(2), 353-392.

Boehe, D., \& Jiménez, A. (2018). Does the sequencing of related and unrelated export diversification matter? Evidence from Colombian exporters. International Business Review, 27(6), 1141-1149.

Brambilla, I., Lederman, D., \& Porto, G. (2012). Exports, export destinations, and skills. American Economic Review, 102(7), 3406-3438.

Bryman, A., \& Bell, E. (2015). Business research methods. New York: Oxford University Press.

Cao, L., Navare, J., \& Jin, Z. (2018). Business model innovation: How the international retailers rebuild their core business logic in a new host country. International Business Review, 27(3), 543562.

Casillas, J. C., Barbero, J. L., \& Sapienza, H. J. (2015). Knowledge acquisition, learning, and the initial pace of internationalization. International Business Review, 24, 102-114.

Collinson, S., \& Liu, Y. (2019). Recombination for innovation: performance outcomes from international partnerships in China. $R \& D$ Management, 49(1), 46-63.

Colton, D., \& Covert, R. (2007). Designing and Constructing Instruments for Social Research and Evaluation. San Francisco (CA): John Wiley \& Sons.

Cope, J. (2005). Towards a dynamic learning perspective of entrepreneurship. Entrepreneurship Theory \& Practice, 29(4), 373-397.

Creswell, J.W., \& Clark, V.L.P. (2017). Designing and conducting mixed methods research. Sage publications.

D’Angelo, A., Majocchi, A., Zucchella, A., \& Buck, T. (2013). Geographical pathways for SME internationalization: Insights from an Italian sample. International Marketing Review, 30, 80-105.

Das, S., Roberts, M.J., \& Tybout, J.R. (2007). Market entry costs, producer heterogeneity, and export dynamics. Econometrica, 75(3), 837-873. 
Eaton, J., Kortum, S., \& Kramarz, F. (2004). Dissecting trade: Firms, industries, and export destinations. American Economic Review, 94(2), 150-154.

Eisenhardt, K. M., \& Martin, J. A. (2000). Dynamic capabilities: what are they? Strategic Management Journal, 21(10-11), 1105-1121.

Felin, T., Foss, N. J., Heimeriks, K. H., \& Madsen, T. L. (2012). Microfoundations of routines and capabilities: Individuals, processes, and structure. Journal of Management Studies, 49(8), 13511374.

Felin, T., Foss, N. J., \& Ployhart, R. E. (2015). The microfoundations movement in strategy and organization theory. Academy of Management Annals, 9(1), 575-632.

Fletcher, M., \& Harris, S. (2012). Knowledge acquisition for the internationalization of the smaller firm: Content and sources. International Business Review, 21(4), 631-647.

Ganotakis, P., \& Love, J. H. (2012). Export propensity, export intensity and firm performance: The role of the Entrepreneurial Founding Team. Journal of International Business Studies, 43, 693-718.

Gavetti, G. (2012). Toward a behavioral theory of strategy. Organization Science, 23(1), 267-285.

Gilbert, B.A., McDougall, P.P., \& Audretsch, D.B. (2006). New venture growth: A review and extension. Journal of Management, 32(6), 926-950.

Gomes, E., Vendrell-Herrero, F., Mellahi, K., Angwin, D., \& Sousa, C. (2018). Testing the selfselection theory in high corruption environments: Evidence from African SMEs. International Marketing Review, 35(5), 733-759.

Greene, W. (2003). Econometric Analysis (5th Ed.). Upper Saddle River, New Jersey: Prentice-Hall.

Greene, W. (2008). Functional forms for the negative binomial model for count data. Economics Letters, 99(3), 585-590.

Greene, J.C., Caracelli, V.J., \& Graham, W.F. (1989). Toward a conceptual framework for mixedmethod evaluation designs. Educational Evaluation and Policy Analysis, 11(3), 255-274.

Greiner, L.E. (1972). Evolution and revolution as organizations grow. Harvard Business Review, 50(3), 37-46.

Headd, B. (2003). Redefining business success: distinguishing between closure and failure. Small Business Economics, 21(1), 51-62.

Huber, G.P. (1991). Organizational learning: The contributing processes and the literatures. Organization Science, 2(1), 88-115.

Johanson, J., \& Vahlne, J. E. (1977). The internationalization process of the firm - A model of knowledge development and increasing foreign market commitment. Journal of International Business Studies, 8, 23-32.

Jones, M.V., Coviello, N., \& Tang, Y.K. (2011). International entrepreneurship research (1989-2009): a domain ontology and thematic analysis. Journal of Business Venturing, 26(6), 632-659. 
Junni, P., Sarala, R.M., Tarba, S.Y., Liu, Y., \& Cooper, C.L. (2015). Guest editors’ introduction: The role of human resources and organizational factors in ambidexterity. Human Resource Management, 54(S1), s1-s28.

Keith, N., Unger, J.M., Rauch, A., \& Frese, M. (2016). Informal learning and entrepreneurial success: A longitudinal study of deliberate practice among small business owners. Applied Psychology: An International Review, 65(3), 515-540.

Knight, G.A., \& Cavusgil, S.T. (2004). Innovation, organizational capabilities, and the born-global firm. Journal of International Business Studies, 35(2), 124-141.

Lafuente, E., Stoian, C., \& Rialp, J. (2015). From Export Entry to De-internationalisation through Entrepreneurial Attributes. Journal of Small Business and Enterprise Development, 22(1), 21-37.

Lafuente, E., Vaillant, Y., \& Moreno-Gómez, J. (2018). Transition in-and-out of exporting and its impact on employment growth. International Journal of Emerging Markets, 13(6), 1907-1927.

Lafuente, E., Vaillant, Y., \& Leiva, J.C. (2018). Sustainable and Traditional Product Innovation without Scale and Experience, but only for KIBS! Sustainability, 10(4), 1169.

Lafuente, E., Vaillant, Y., Vendrell-Herrero, F., \& Gomes, E. (2018). Bouncing back from failure: Entrepreneurial resilience and the internationalization of subsequent ventures created by serial entrepreneurs. Applied Psychology: An International Review, 68(4), 658-694.

Laufs, K., \& Schwens, C. (2014). Foreign market entry mode choice of small and medium-sized enterprises: A systematic review and future research agenda. International Business Review, 23(6), 1109-1126.

Li, R., Liu, Y. \& Bustinza, O.F. (2018). FDI, service intensity, and international marketing agility: The case of export quality of Chinese enterprises. International Marketing Review, 36(2), 213-238.

Liu, Y. (2020). Contextualising risk while building resilience: Returnee vs. local entrepreneurs in China. Applied Psychology: An International Review, 69(2), 415-443.

Liu, Y., \& Almor, T. (2016). How culture influences the way entrepreneurs deal with uncertainty in inter-organizational relationships: The case of returnee versus local entrepreneurs in China. International Business Review, 25(1), 4-14.

Liu, Y. \& Huang, Q. (2018). University capability as a micro-foundation for the Triple Helix model: the case of China. Technovation, 76-77, 40-50.

Love, J.H., Roper, S., \& Zhou, Y. (2016). Experience, age and exporting performance in UK SMEs. International Business Review, 25(4), 806-819.

MacMillan, I.C. (1986), “Executive forum: To really learn about entrepreneurship, let’s study habitual entrepreneurs”, Journal of Business Venturing, 1, 211-243.

Majocchi, A., Bacchiocchi, E., \& Mayrhofer, U. (2005). Firm size, business experience and export intensity in SMEs; a longitudinal approach to complex relationships. International Business Review, 14, 719-738. 
Manova, K., \& Zhang, Z. (2012). Export prices across firms and destinations. Quarterly Journal of Economics, 127(1), 379-436.

Martincus, C.V., \& Carballo, J. (2008). Is export promotion effective in developing countries? Firmlevel evidence on the intensive and the extensive margins of exports. Journal of International Economics, 76(1), 89-106.

Martins, I., Gómez-Araujo, E., \& Vaillant, Y. (2014). The effect of export behavior on ownermanager's commitment to innovation in Colombia: insights from learning approach. Cuadernos de Administración, 27(49), 135-153.

Martins, I., Goméz-Araujo, E., \& Vaillant, Y. (2015). Mutual effects between innovation commitment and exports: evidence from the owner-manager in Colombia. Journal of Technology Management \& Innovation, 10(1), 103-116.

Miocevic, D., \& Crnjak-Karanovic, B. (2011). Cognitive and information-based capabilities in the internationalisation of small and medium-sized enterprises: the case of Croatian exporters. Journal of Small Business Management, 49(4), 537-557.

Monge-González, R., Leiva, J.C., Torres-Carballo, F., Alfaro-Ureña, A., Morales-Sandoval, C., \& Solano-Gómez, Ángela. (2017). Gazelles firms in Costa Rica: an exploratory study of identification and characterization. TEC Empresarial, 11(3), 17-26.

Morse, J.M. (1991). Approaches to qualitative-quantitative methodological triangulation. Nursing Research, 40(2), 120-123.

Morse, J.M., \& Niehaus, L. (2009). Mixed methods design: Principles and procedures. Walnut Creek (CA): Left Coast Press.

OECD (2016). OECD Economic Surveys: Costa Rica. OECD Publishing: Paris.

OECD (2017). OECD Reviews of Innovation Policy: Costa Rica 2017. OECD Publishing: Paris.

Parker, S.C. (2013). Do serial entrepreneurs run successively better-performing businesses? Journal of Business Venturing, 28(5), 652-666.

Peiris, I.K., Akoorie, M.E., \& Sinha P. (2012). International entrepreneurship: a critical analysis of studies in the past two decades and future directions for research. Journal of International Entrepreneurship, 10(4), 279-234.

Raschke, R. (2010). Process-based view of agility: the value contribution of IT and the effects on process outcomes. International Journal of Accounting Information Systems, 11(4), 297-313.

Rialp, A., Rialp, J., \& Knight, G.A. (2005). The phenomenon of early internationalizing firms: what do we know after a decade (1993-2003) of scientific inquiry? International Business Review, 14(2), 147-166.

Rialp, A., Rialp, J., Urbano, D., \& Vaillant, Y. (2005). The born-global phenomenon: A comparative case study research. Journal of International Entrepreneurship, 3(2), 133-171.

Roper, S., \& Love, J.H. (2002). Innovation and export performance: Evidence from UK and German manufacturing plants. Research Policy, 31, 1087-1102. 
Salvato, C., \& Rerup, C. (2011). Beyond collective entities: Multilevel research on organizational routines and capabilities. Journal of Management, 37(2), 468-490.

Schmidt, T., \& Sofka, W. (2009). Liability of foreignness as a barrier to knowledge spillovers: Lost in translation? Journal of International Management, 15, 460-474.

Simmons, S.A., Carr, J.C., Hsu, D.K. \& Shu, C. (2016). The regulatory fit of serial entrepreneurship intentions. Applied Psychology: An International Review, 65(3), 603-627.

Stephan, U., Patterson, M., Kelly, C., \& Mair, J. (2016). Organizations driving positive social change: A review and an integrative framework of change processes. Journal of Management, 42(5), 12501281.

Teddlie, C., \& Tashakkori, A. (2009). Foundations of mixed methods research: Integrating quantitative and qualitative approaches in the social and behavioral sciences. Sage publications.

Teece, D. J. (2007). Explicating dynamic capabilities: the nature and microfoundations of (sustainable) enterprise performance. Strategic Management Journal, 28(13), 1319-1350.

Theodosiou, M., \& Leonidou, L.C. (2003). Standardization versus adaptation of international marketing strategy: an integrative assessment of the empirical research. International Business Review, 12(2), 141-171.

Toft-Kehler, R., Wennberg, K., \& Kim, P. (2014). Practice makes perfect: Entrepreneurial-experience curves and venture performance. Journal of Business Venturing, 29(4), 453-470.

Ucbasaran, D., Lockett, A., Wright, M., \& Westhead, P. (2003). Entrepreneurial founder teams: Factors associated with member entry and exit. Entrepreneurship Theory \& Practice, 28(2), 107128.

Ucbasaran, D., Shepherd, D.A., Lockett, A., \& Lyon, S.J. (2013). Life after Business Failure: The Process and Consequences of Business Failure for Entrepreneurs. Journal of Management, 39(1), 163-202.

Ucbasaran, D., Westhead, P., \& Wright, M. (2006). Habitual Entrepreneurs. Aldershot, UK: Edward Elgar Publishing.

Ucbasaran, D., Westhead, P., \& Wright, M. (2008) Opportunity identification and pursuit: does an entrepreneur’s human capital matter? Small Business Economics, 30(2), 153-173.

Ucbasaran, D., Westhead, P., \& Wright, M. (2009). The extent and nature of opportunity identification by experienced entrepreneurs. Journal of Business Venturing, 24(2), 99-115.

Ucbasaran, D., Westhead, P., Wright, M., \& Flores, M. (2010). The nature of entrepreneurial experience, business failure, and comparative optimism. Journal of Business Venturing, 25(6), 541555.

Vaillant, Y., Urbano, D., Criado, J. R., \& Criado, À. R. (2006). Un estudio cualitativo y exploratorio de cuatro nuevas empresas exportadoras. Cuadernos de Economía y Dirección de la Empresa, (29), $107-132$. 
Vaillant, Y., Lafuente, E., \& Bayon, M.C. (2019). Early internationalization patterns and export market persistence: a pseudo-panel data analysis. Small Business Economics, 53(3), 669.686.

Vaillant, Y, \& Lafuente, E. (2019a). Entrepreneurial Experience and the Innovativeness of Serial Entrepreneurs. Management Decision. 57(11), 2869-2889.

Vaillant, Y., \& Lafuente, E. (2019b). The increased international propensity of serial entrepreneurs demonstrating ambidextrous strategic agility: A precursor to international marketing agility. International Marketing Review, 36(2), 239-259.

Van de Ven, A. (2007). Engaged Scholarship. Oxford, UK: Oxford University Press.

Van Praag, C.M. \& Cramer, J.S. (2001). The roots of entrepreneurship and labour demand: individual ability and low risk aversion. Economica, 68(269), 45-62.

Vendrell-Herrero, F., Gomes, E., Collinson, S., Parry, G., \& Bustinza, O.F. (2018). Selling digital services abroad: How do extrinsic attributes influence foreign consumers' purchase intentions? International Business Review, 27(1), 173-185.

Vendrell-Herrero, F., Gomes, E., Mellahi, K. \& Child, J. (2017). Building international business bridges in geographically isolated areas: the role of foreign market focus and outward looking competences in Latin American SMEs. Journal of World Business, 52(4), 489-502.

Volberda, H. W., Foss, N. J., \& Lyles, M. A. (2010). Perspective-Absorbing the concept of absorptive capacity: How to realize its potential in the organization field. Organization science, 21(4), 931-951.

Westhead, P., Ucbasaran, D. and Wright, M. (2005). Decisions, Actions, and Performance: Do Novice, Serial, and Portfolio Entrepreneurs Differ? Journal of Small Business Management, 43(4), 393-417.

Westhead, P., Wright, M., \& Ucbasaran, D. (2001). The internationalization of new and small firms: A resource-based view. Journal of Business Venturing, 16(4), 333-358.

World Economic Forum (2016). The Global Competitiveness Report 2016-2017. World Economic Forum: Geneva, Switzerland.

Yeoh, P. (2004). International learning: Antecedents and performance implications among newly internationalizing companies in an exporting context. International Marketing Review, 21(4-5), 511-535.

Zollo, M., \& Winter, S. G. (2002). Deliberate learning and the evolution of dynamic capabilities. Organization Science, 13(3), 339-351. 


\section{List of figures}

Figure 1. Frequency distribution of the estimated number of export destinations targeted by the sampled firms

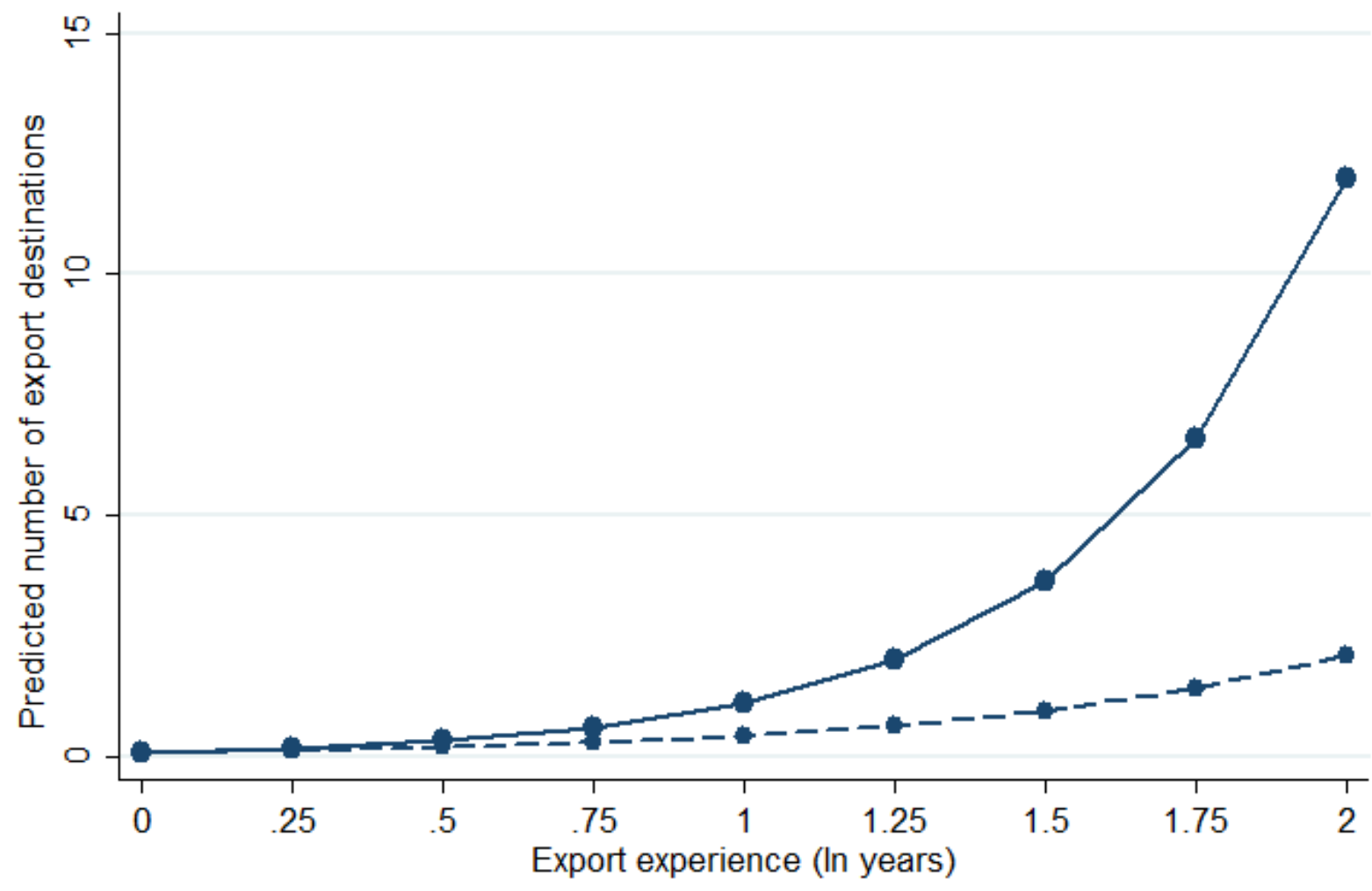

- - - - Novice entrepreneur

$\longrightarrow$ Serial entrepreneur 


\section{List of tables}

Table 1. Descriptive statistics and bivariate correlations

\begin{tabular}{|c|c|c|c|c|c|c|c|c|c|c|c|c|c|c|c|c|c|}
\hline & & Mean & Std. dev. & 1 & 2 & 3 & 4 & 5 & 6 & 7 & 8 & 9 & 10 & 11 & 12 & 13 & 14 \\
\hline 1 & Exporter & 0.2195 & 0.4165 & 1 & & & & & & & & & & & & & \\
\hline 2 & $\begin{array}{l}\text { Export } \\
\text { destinations }\end{array}$ & 0.5001 & 1.2497 & $0.76^{* * *}$ & 1 & & & & & & & & & & & & \\
\hline 3 & $\begin{array}{l}\text { Serial } \\
\text { entrepreneur }\end{array}$ & 0.1829 & 0.3890 & 0.05 & $0.19^{*}$ & 1 & & & & & & & & & & & \\
\hline 4 & $\begin{array}{l}\text { Export } \\
\text { experience }\end{array}$ & 2.68 & 7.41 & $0.69^{* * *}$ & $0.33^{* * *}$ & -0.08 & 1 & & & & & & & & & & \\
\hline 5 & $\begin{array}{l}\text { Labor } \\
\text { experience }\end{array}$ & 20.09 & 11.33 & 0.03 & -0.03 & 0.14 & 0.11 & 1 & & & & & & & & & \\
\hline 6 & $\begin{array}{l}\text { Entrepreneur's } \\
\text { gender }\end{array}$ & 0.5854 & 0.4957 & 0.15 & 0.10 & 0.08 & 0.17 & $0.23^{* *}$ & 1 & & & & & & & & \\
\hline 7 & $\begin{array}{l}\text { Entrepreneur's } \\
\text { age }\end{array}$ & 42.10 & 10.97 & 0.07 & 0.01 & 0.10 & 0.11 & $0.89^{* * *}$ & $0.19^{*}$ & 1 & & & & & & & \\
\hline 8 & $\begin{array}{l}\text { Management } \\
\text { studies }\end{array}$ & 0.5488 & 0.5007 & -0.05 & 0.07 & 0.05 & -0.10 & $-0.18^{*}$ & -0.07 & -0.18 & 1 & & & & & & \\
\hline 9 & $\begin{array}{l}\text { Size (micro } \\
\text { business) }\end{array}$ & 0.8293 & 0.3786 & $-0.31^{* * *}$ & $-0.26^{* *}$ & 0.05 & -0.22 & 0.08 & 0.01 & 0.10 & 0.11 & 1 & & & & & \\
\hline 10 & Business age & 14.85 & 16.88 & $0.35^{* * *}$ & $0.20^{*}$ & 0.07 & $0.47^{* * *}$ & $0.30^{* * *}$ & $0.21^{*}$ & $0.24^{* *}$ & -0.06 & $-0.21^{*}$ & 1 & & & & \\
\hline 11 & $\begin{array}{l}\text { Use of new } \\
\text { technologies }\end{array}$ & 0.0488 & 0.2167 & $0.29^{* * *}$ & 0.14 & -0.11 & $0.24^{* *}$ & -0.15 & $0.19^{*}$ & -0.13 & $0.21^{*}$ & $-0.20^{*}$ & 0.03 & 1 & & & \\
\hline 12 & Manufacturing & 0.1341 & 0.3429 & 0.14 & 0.10 & -0.09 & 0.17 & $-0.23^{* *}$ & -0.03 & -0.02 & -0.15 & -0.11 & 0.09 & -0.09 & 1 & & \\
\hline 13 & $\begin{array}{l}\text { Business } \\
\text { services }\end{array}$ & 0.4512 & 0.5007 & 0.05 & -0.05 & -0.11 & 0.08 & 0.03 & 0.12 & -0.03 & $0.23^{* *}$ & $0.22^{*}$ & -0.07 & 0.14 & $-0.36^{* * *}$ & 1 & \\
\hline 14 & Retail & 0.4146 & 0.4957 & -0.15 & -0.02 & 0.18 & $-0.19^{*}$ & 0.12 & -0.10 & 0.04 & -0.13 & -0.14 & 0.01 & -0.08 & $-0.33^{* * *}$ & $-0.76^{* * *}$ & 1 \\
\hline 15 & Capital & 0.5366 & 0.5017 & -0.04 & -0.06 & 0.00 & -0.13 & 0.01 & 0.11 & -0.03 & 0.09 & -0.03 & -0.10 & $0.21^{*}$ & 0.01 & 0.15 & -0.16 \\
\hline
\end{tabular}

$*, * *, * * *$ indicate significance at the $10 \%, 5 \%$ and $1 \%$, respectively. 
Table 2. Distribution of entrepreneurs by export status and type of entrepreneur

\begin{tabular}{|l|c|c|}
\hline Export status / & \multicolumn{2}{|c|}{ Type of entrepreneur } \\
& $\begin{array}{c}\text { Novice } \\
\text { (no entrepreneurial experience) }\end{array}$ & $\begin{array}{c}\text { Serial } \\
\text { (past entrepreneurial experience) }\end{array}$ \\
\hline Exporter & $\begin{array}{c}20.90 \% \\
\text { (export destinations: 1.86) }\end{array}$ & $\begin{array}{c}26.67 \% \\
\text { (export destinations: 3.75) }\end{array}$ \\
\hline No exporter & $79.10 \%$ & $73.33 \%$ \\
\hline
\end{tabular}

Table 3. Quantitative analysis: Results of the negative binomial regression model

\begin{tabular}{|c|c|c|}
\hline & \multicolumn{2}{|c|}{ Dependent variable: Export destinations } \\
\hline & Model 1 & Model 2 \\
\hline & $\begin{array}{l}\text { Coefficient } \\
\text { (std. error) }\end{array}$ & $\begin{array}{l}\text { Coefficient } \\
\text { (std. error) }\end{array}$ \\
\hline Serial entrepreneur & $1.1195(0.4793)^{* *}$ & $0.1144(0.6848)$ \\
\hline Export experience (ln years) & $1.8717(0.3576)^{* * *}$ & $1.5818(0.4092)^{* * *}$ \\
\hline Serial entrepreneur $\times$ export experience & & $0.8113(0.4299) *$ \\
\hline Labor experience (ln years) & $0.4928(0.8535)$ & $0.5429(0.7869)$ \\
\hline Gender & $-0.0426(0.4894)$ & $0.0235(0.6486)$ \\
\hline Entrepreneur age (ln years) & $-0.9302(1.7306)$ & $-0.9704(1.5861)$ \\
\hline Management studies & $1.4059(0.5529)^{* * *}$ & $1.2586(0.5313)^{* *}$ \\
\hline Size (micro business) & $-1.2097(0.4969)^{* *}$ & $-0.9945(0.5739)^{*}$ \\
\hline Business age (ln years) & $-0.7823(0.3444)^{* *}$ & $-0.6810(0.2867)^{* *}$ \\
\hline Use of new technologies & $0.2354(0.9778)$ & $0.2430(0.9837)$ \\
\hline Manufacturing & $-0.3918(0.4714)$ & $-0.1590(0.4901)$ \\
\hline Business services & $-0.5925(0.4959)$ & $-0.6082(0.6690)$ \\
\hline Capital & $0.7024(0.4286)^{*}$ & $0.8559(0.4568)^{*}$ \\
\hline Intercept & $0.7195(4.6936)$ & $0.6648(4.1956)$ \\
\hline Wald test (chi2) & $99.47 * * *$ & $157.59 * * *$ \\
\hline Pseudo R2 (McFadden) & 0.3327 & 0.3440 \\
\hline Log likelihood & -47.7098 & -46.9011 \\
\hline Alpha value & $0.8451(0.4132)^{* *}$ & $0.7620(0.3848)^{* *}$ \\
\hline Chi2 test Alpha $=0$ & $5.66 * * *$ & $4.13^{* *}$ \\
\hline Average VIF (minimum-maximum) & $1.91(1.09-5.17)$ & $1.94(1.15-5.38)$ \\
\hline Number of cases & 82 & 82 \\
\hline
\end{tabular}

Robust standard errors adjusted by heteroskedasticity are presented in parentheses. *, **, *** indicate significance at the $10 \%, 5 \%$ and $1 \%$, respectively. 
Table 4. Qualitative analysis: Characteristics of the entrepreneurs and their current business

\begin{tabular}{|c|c|c|c|c|}
\hline & $\begin{array}{l}\text { Case 1: serial entrepreneur / } \\
\text { low export experience }\end{array}$ & $\begin{array}{l}\text { Case 2: serial entrepreneur / } \\
\text { high export experience }\end{array}$ & $\begin{array}{l}\text { Case 3: serial entrepreneur / } \\
\text { low export diversity }\end{array}$ & $\begin{array}{l}\text { Case 4: serial entrepreneur / } \\
\text { high export diversity }\end{array}$ \\
\hline \multicolumn{5}{|l|}{$\begin{array}{l}\text { Panel A: The } \\
\text { entrepreneur }\end{array}$} \\
\hline Gender / Age & Woman / 34 years old & Male / 36 years old & Male / 55 years old & Man / 49 years old \\
\hline Background & $\begin{array}{l}\text { University studies } \\
\text { Also, the entrepreneur indicated } \\
\text { that she has studies in } \\
\text { management, finance and IT }\end{array}$ & $\begin{array}{l}\text { University studies } \\
\text { The entrepreneur also has studies } \\
\text { in IT technologies }\end{array}$ & $\begin{array}{l}\text { University studies } \\
\text { Also, the entrepreneur } \\
\text { highlighted that he has studies in } \\
\text { management }\end{array}$ & $\begin{array}{l}\text { University studies } \\
\text { Besides, the entrepreneur has } \\
\text { studies in management and } \\
\text { finance }\end{array}$ \\
\hline $\begin{array}{l}\text { Labor market } \\
\text { experience (total) }\end{array}$ & 14 years & 17 years & 39 years & 27 years \\
\hline \multicolumn{5}{|l|}{ Panel B: The business } \\
\hline Business age & 4 years in the market & 10 years in the market & 11 years in the market & 15 years in the market \\
\hline Number of employees & $\begin{array}{l}\text { Micro business (business with up } \\
\text { to } 10 \text { employees) }\end{array}$ & $\begin{array}{l}\text { Small business (between } 11 \text { and } \\
50 \text { employees) }\end{array}$ & $\begin{array}{l}\text { Micro business (business with up } \\
\text { to } 10 \text { employees) }\end{array}$ & $\begin{array}{l}\text { Small business (between } 11 \text { and } \\
50 \text { employees) }\end{array}$ \\
\hline Sector / activity & \begin{tabular}{|l|} 
Business services \\
The business offers to its clients \\
advisory and consultancy \\
services in management, finance \\
and accounting issues
\end{tabular} & \begin{tabular}{|l|} 
Business services \\
The business develops software \\
solutions to improve operational \\
processes (automation)
\end{tabular} & \begin{tabular}{|l|} 
Manufacturing \\
The business designs and \\
manufactures materials that \\
support marketing campaigns \\
and branding
\end{tabular} & $\begin{array}{l}\text { Manufacturing } \\
\text { The business produces cosmetic } \\
\text { products using natural } \\
\text { ingredients exclusively }\end{array}$ \\
\hline Geographic location & San José & San José & San José & Heredia \\
\hline
\end{tabular}


Table 5. Qualitative analysis: Characteristics of past entrepreneurial experience and export market experience

\begin{tabular}{|c|c|c|c|c|}
\hline & $\begin{array}{l}\text { Case 1: serial entrepreneur / } \\
\text { low export experience }\end{array}$ & $\begin{array}{l}\text { Case 2: serial entrepreneur / } \\
\text { high export experience }\end{array}$ & $\begin{array}{l}\text { Case 3: serial entrepreneur / } \\
\text { low export diversity }\end{array}$ & $\begin{array}{l}\text { Case 4: serial entrepreneur / } \\
\text { high export diversity }\end{array}$ \\
\hline \multicolumn{5}{|l|}{$\begin{array}{l}\text { Panel A: Past } \\
\text { entrepreneurial } \\
\text { experience } \\
\end{array}$} \\
\hline $\begin{array}{l}\text { Number of } \\
\text { businesses created } \\
\text { in the past }\end{array}$ & $\begin{array}{l}\text { The entrepreneur created } 4 \text { firms in } \\
\text { the past, in 2002, 2004, } 2009 \text { and } \\
2010 \text {. Also, the businesses created in } \\
2009 \text { and } 2010 \text { are still operational. } \\
\text { The entrepreneur manifested a } \\
\text { mixed valuation of her past } \\
\text { entrepreneurial experience: negative } \\
\text { for the first } 2 \text { firms and positive for } \\
\text { the firms created in } 2009 \text { and } 2010\end{array}$ & $\begin{array}{l}\text { The entrepreneur has created } 2 \\
\text { firms in the past, in } 1999 \text { and in } \\
2004 \text {. } \\
\text { The entrepreneur has a positive } \\
\text { valuation of his past } \\
\text { entrepreneurial experience }\end{array}$ & $\begin{array}{l}\text { The entrepreneur has created } 2 \\
\text { businesses in the past, in } 1996 \\
\text { and in } 2002 . \\
\text { The entrepreneur indicated that } \\
\text { he positively values his past } \\
\text { entrepreneurial experience }\end{array}$ & $\begin{array}{l}\text { The entrepreneur has created a } \\
\text { total number of } 5 \text { businesses. The } \\
\text { businesses were created in } 1994 \text {, } \\
\text { 1998, 2000, } 2006 \text { and } 2012 \text {. } \\
\text { The entrepreneur states that his } \\
\text { past entrepreneurial experience is } \\
\text { mostly positive }\end{array}$ \\
\hline $\begin{array}{l}\text { Sector / activity of } \\
\text { previous businesses }\end{array}$ & $\begin{array}{l}\text { The previous businesses operated in } \\
\text { retail and business service sectors } \\
\text { In this case, the entrepreneur } \\
\text { highlighted the low connection } \\
\text { between the first } 2 \text { firms and her } \\
\text { actual business, whereas there is a } \\
\text { relatively high similarity in the } \\
\text { economic activity of her last } 2 \text { firms } \\
\text { and her current business }\end{array}$ & $\begin{array}{l}\text { Because of the highly specific } \\
\text { nature of his knowledge and } \\
\text { work, the economic activity of } \\
\text { his past and current business is } \\
\text { very similar (IT solutions) }\end{array}$ & $\begin{array}{l}\text { The previous businesses operated } \\
\text { in the business services and in } \\
\text { retailing sectors. } \\
\text { In this case, the entrepreneur } \\
\text { indicated that there is a relatively } \\
\text { low similarity in the economic } \\
\text { activity of his past and current } \\
\text { businesses }\end{array}$ & $\begin{array}{l}\text { The first } 4 \text { businesses operated in } \\
\text { retail sectors, while the } \\
\text { remaining } 2 \text { businesses provided } \\
\text { services to businesses. } \\
\text { There is a low relationship } \\
\text { between the economic activity of } \\
\text { past viz.-a-viz. the current firm }\end{array}$ \\
\hline $\begin{array}{l}\text { Entrepreneurial } \\
\text { team }\end{array}$ & $\begin{array}{l}\text { In this case a number of differences } \\
\text { emerge. The entrepreneur teamed-up } \\
\text { with different partners to create her } \\
\text { first } 2 \text { businesses; however, she } \\
\text { decided to create alone the third and } \\
\text { fourth business }\end{array}$ & $\begin{array}{l}\text { The entrepreneur highlighted that } \\
\text { he created his first business } \\
\text { alone, but he worked together } \\
\text { with a partner create his second } \\
\text { previous business }\end{array}$ & $\begin{array}{l}\text { The entrepreneur created his past } \\
\text { business alone, while the second } \\
\text { business was created with a } \\
\text { partner }\end{array}$ & $\begin{array}{l}\text { The entrepreneur created the first } \\
\text { and the last firm with a partner } \\
\text { (different partners), while he } \\
\text { created the other } 4 \text { firms alone }\end{array}$ \\
\hline \multicolumn{5}{|l|}{$\begin{array}{l}\text { Panel B: Export } \\
\text { experience }\end{array}$} \\
\hline $\begin{array}{l}\text { Export market } \\
\text { experience }\end{array}$ & $\begin{array}{l}\text { The business has } 2 \text { years of export } \\
\text { market experience }\end{array}$ & $\begin{array}{l}\text { The business has } 8 \text { years of } \\
\text { export market experience }\end{array}$ & $\begin{array}{l}\text { The business has } 3 \text { years of } \\
\text { export market experience }\end{array}$ & $\begin{array}{l}\text { The business has } 5 \text { years of } \\
\text { export market experience }\end{array}$ \\
\hline Export diversity & The business exports to 1 country & $\begin{array}{l}\text { The business exports to } 2 \\
\text { countries }\end{array}$ & The business exports to 1 country & $\begin{array}{l}\text { The business exports to } 5 \\
\text { different countries }\end{array}$ \\
\hline
\end{tabular}




\section{Appendix}

Table A1. Robustness checks: Results of the probit and ordered probit model

\begin{tabular}{|c|c|c|c|c|c|}
\hline & \multicolumn{2}{|c|}{ Probit model: Export propensity } & \multicolumn{3}{|c|}{$\begin{array}{l}\text { Ordered probit model: Export intensity } \\
(0=\text { no export, } 1=\text { exports } 1 \%-25 \%, 2=\text { exports } 25 \%-50 \%)\end{array}$} \\
\hline & $\begin{array}{l}\text { Coefficient } \\
\text { (std. error) }\end{array}$ & $\begin{array}{l}\text { Average marginal } \\
\text { effect (AME) }\end{array}$ & $\begin{array}{l}\text { Coefficient } \\
\text { (std. error) }\end{array}$ & $\begin{array}{c}\text { AME: } \\
\text { Exports } 1 \%-25 \%\end{array}$ & $\begin{array}{c}\text { AME: } \\
\text { Exports 26\%-50\% }\end{array}$ \\
\hline Serial entrepreneur & $0.7817(0.4599)^{*}$ & $0.1587(0.0952)^{*}$ & $0.5422(0.3073)^{*}$ & $0.0986(0.0558)^{*}$ & $0.0229(0.0208)$ \\
\hline Labor experience (ln years) & $-0.9205(0.5630)$ & $-0.1868(0.1202)$ & $-0.5420(0.4661)$ & $-0.0986(0.0903)$ & $-0.0229(0.0239)$ \\
\hline Gender & $0.2272(0.3988)$ & $0.0461(0.0799)$ & $0.1471(0.3767)$ & $0.0267(0.0686)$ & $0.0062(0.0153)$ \\
\hline Entrepreneur age (ln years) & $1.5696(1.2417)$ & $0.3186(0.2599)$ & $0.9190(1.0644)$ & $0.1671(0.2015)$ & $0.0389(0.0454)$ \\
\hline Management studies & $-0.3130(0.3724)$ & $-0.0635(0.0756)$ & $-0.0574(0.3474)$ & $-0.0104(0.0636)$ & $-0.0024(0.0143)$ \\
\hline Size (micro business) & $-0.9409(0.4978)^{*}$ & $-0.1910(0.1001)^{*}$ & $-0.7565(0.4218) *$ & $-0.1375(0.0776)^{*}$ & $-0.0320(0.0221)$ \\
\hline Business age (ln years) & $0.5903(0.2520)^{* *}$ & $0.1198(0.0511)^{* *}$ & $0.5157(0.1980)^{* * *}$ & $0.0938(0.0359)^{* * *}$ & $0.0218(0.0151)$ \\
\hline Use of new technologies & $2.0717(0.6477) * * *$ & $0.4205(0.1194)^{* * *}$ & $0.8952(0.6858)$ & $0.1628(0.1247)$ & $0.0378(0.0247)$ \\
\hline Manufacturing & $0.6855(0.6868)$ & $0.1391(0.1364)$ & $0.8430(0.6027)$ & $0.1533(0.1028)$ & $0.0356(0.0321)$ \\
\hline Business services & $0.7428(0.3742)^{* *}$ & $0.1508(0.0751)^{* *}$ & $0.5689(0.3265)^{*}$ & $0.1035(0.0588)^{*}$ & $0.0241(0.0206)$ \\
\hline Capital & $-0.2712(0.3860)$ & $-0.0550(0.0756)$ & $-0.0453(0.3517)$ & $-0.0082(0.0639)$ & $-0.0019(0.0144)$ \\
\hline Intercept & $-5.2830(3.7140)$ & & & & \\
\hline Cut 1 (exports= 1\%-25\%) & & & 3.9421 (3.1577) & & \\
\hline Cut 2 (exports= 26\%-50\%) & & & $5.5056(3.2768)$ & & \\
\hline Wald test (chi2) & $38.42 * * *$ & & $30.59 * * *$ & & \\
\hline Pseudo R2 (McFadden) & 0.2979 & & 0.2209 & & \\
\hline Log likelihood & -30.2993 & & -38.5161 & & \\
\hline Average VIF (min-max) & $1.89(1.09-5.15)$ & & $1.89(1.09-5.15)$ & & \\
\hline Number of cases & 82 & & 82 & & \\
\hline
\end{tabular}

Robust standard errors adjusted by heteroskedasticity are presented in parentheses. For each independent variable (x) the average marginal effect (AME) is estimated as

$A M E_{\mathbf{x}}=\frac{1}{N} \sum_{i=1}^{N}\left\{F\left(\beta \mathbf{x} \mid \mathbf{x}_{i}=1\right)-F\left(\beta \mathbf{x} \mid \mathbf{x}_{i}=0\right)\right\} . *, * *, * * *$ indicate significance at the $10 \%, 5 \%$ and $1 \%$, respectively. 